Abstracta Iranica Abstracta Iranica

Revue bibliographique pour le domaine irano-aryen

Volume 27 | 2006

Comptes rendus des publications de 2004

\title{
«La scène du char sur les monnaies de Sidon d'époque perse ». Transeuphratène, 27 (2004), pp. 89-108.
}

\section{Astrid Nunn}

\section{(2) OpenEdition}

1 Journals

\section{Édition électronique}

URL : http://journals.openedition.org/abstractairanica/5703

DOI : 10.4000/abstractairanica.5703

ISSN : 1961-960X

Éditeur :

CNRS (UMR 7528 Mondes iraniens et indiens), Éditions de l'IFRI

\section{Édition imprimée}

Date de publication : 15 mai 2006

ISSN : 0240-8910

Référence électronique

Astrid Nunn, " «La scène du char sur les monnaies de Sidon d'époque perse ». Transeuphratène, 27 (2004), pp. 89-108. », Abstracta Iranica [En ligne], Volume 27 | 2006, document 71, mis en ligne le 02 janvier 2007, consulté le 25 septembre 2020. URL : http://journals.openedition.org/abstractairanica/ 5703 ; DOI : https://doi.org/10.4000/abstractairanica.5703

Ce document a été généré automatiquement le 25 septembre 2020.

Tous droits réservés 


\title{
« La scène du char sur les monnaies de Sidon d'époque perse ». Transeuphratène, 27 (2004), pp. 89-108.
}

\author{
Astrid Nunn
}

Depuis longtemps déjà existe un débat sur l'identification des deux personnages qui se tiennent dans le char représenté sur certaines monnaies sidoniennes d'époque achéménide : roi de Sidon et son serviteur, scène d'allégeance du roi de Sidon au roi des Perses ou procession cultuelle d'une divinité locale avec la participation du roi de Sidon? Les AA. démontrent que les deux premières hypothèses sont fausses, et que seule la troisième explication entre en ligne de compte. En effet la couronne dentelée et le vêtement pourraient être un emprunt aux coutumes achéménides et portés par un Phénicien. Le char des monnaies n'est pas un char royal perse et une scène figurant la soumission du roi sidonien au roi perse est impensable au moment de la frappe de ces monnaies. La scène ne peut être que cultuelle vu le sceptre que tient le suivant qui suit à pied le char. Le personnage transporté est un dieu local (non identifiable) et le suivant pourrait alors être le roi de Sidon.

\section{INDEX}

Thèmes : 3.2.1. Elam 
AUTEURS

ASTRID NUNN

Université de Munich 